Migration Studies - Review of Polish Diaspora nr 2 (172)/2019, http://www.ejournals.eu/Studia-Migracyjne/ 10.4467/25444972SMPP.19.025.10851

\title{
Z Krakowa do Ottawy. Maria Flora Zielińska - kawałek Polski w Kanadzie
}

\author{
MARTA KIJEWSKA-TREMBECKA ${ }^{1}$ \\ Uniwersytet Jagielloński
}

\begin{abstract}
Maria Flora Zielińska, z domu Nałęcz-Odrzywolska, wyjechała z Krakowa w 1957 roku. Wraz z mężem Jankiem osiedli najpierw w Montrealu, później w Ottawie. Maria, kobieta o wielkim temperamencie i sercu, przez ponad pół wieku niestrudzenie pracowała na rzecz ukochanej Polski, Polonii i Kanady. W kraju ukończyła studia rolnicze na UJ, a w Kanadzie bibliotekoznawstwo na McGill University. Czynnie działała w niemal wszystkich ottawskich organizacjach polonijnych, reprezentowała je także na forum ogólnokanadyjskim. Zawodowo związana była z kanadyjskimi bibliotekami: uniwersytecką w Montrealu i Narodową w Ottawie, współtworzyła biblioteki przy instytucjach polonijnych. Zorganizowała i przez ponad 20 lat prowadziła Multilingual Biblioservice, biblioteczney serwis służący kanadyjskim grupom etnicznym. Była to jedna z ważniejszych instytucji powołanych przez rząd P.E. Trudeau w ramach polityki pluralizmu kulturowego. Wielką miłością Marysi pozostał Kraków, gdzie często przyjeżdżała do ostatnich swoich lat, by przejść się po Starym Mieście, iść do Kościoła Mariackiego i do kawiarni Noworola, odwiedzić przyjaciół, po prostu pobyć. Ottawskie mieszkanie Zielińskich zawsze było otwarte dla przybyszów, nie tylko z Polski. Zmarła jesienią 2016 roku w wieku 95 lat.
\end{abstract}

Słowa klucze: Zielińska, Kraków, Kanada, Polonia, biblioteka.

\section{From Kraków to Ottawa. Maria Flora Zielińska - a piece of Poland in Canada}

Maria Flora Zielińska, née Nałęcz-Odrzywolska, left Krakow in 1957. With her husband Janek, she settled first in Montreal, later in Ottawa. Maria, a woman of great temperament and heart, worked tirelessly for her beloved Poland, Polish diaspora and Canada for over half a century. When still in Poland, she completed her studies at the Jagiellonian University, and then in Canada - library studies at McGill University. She was active in almost all Ottawa's Polish diaspora organizations, representing them in the Canadian fora. Professionally, she worked for the university library in Montreal and the National Library Canada in Ottawa, but she also helped establish libraries at Polish diaspora institutions. She created and for over 20 years served as head of the Multilingual Biblioservice, a library service for Canadian ethnic groups within the National Library Canada. It was one of the

\footnotetext{
1 Kontakt: marta.kijewska-trembecka@uj.edu.pl
} 
most important institutions supported by the P.E. Trudeau government as part Canada's cultural pluralism policy. Krakow remained her great love until the end of her life. She often returned to the city to stroll in the Old Town, to go to St. Mary's Church and to the Noworol Café, to visit friends, just to stay in town for a while. In the Zielińskis' Ottawa apartment newcomers were always welcome, not only those from Poland. She died in the fall of 2016 at the age of 95.

Keywords: Zielinska, Kraków, Canada, Polonia, library

Wszyscy nazywali ją Marysią, a najbliżsi Misią. To nie postać wielkości Kazimierza Gzowskiego czy Stanleya Haidasza, ale jedna z tych Polek w Kanadzie, wcale nie tak licznych, która będąc imigrantką, osiągnęła wysoką pozycję w karierze zawodowej, pełniła bowiem ważną funkcję w administracji federalnej Kanady. Łączyła ją z działalnością na rzecz polskiej grupy etnicznej i ciągłą tęsknotą za Polską, która dla niej oznaczała przede wszystkim Kraków².

Maria Flora z Sas-Nałęcz Odrzywolskich Zielińska, urodziła się w znanej krakowskiej rodzinie w roku 1921, zmarła w Ottawie we wrześniu 2016 roku. Przez ponad pół wieku dzieliła życie z Jankiem Zielińskim³ ${ }^{3}$ zmarłym w Ottawie w 2004 roku. W Kanadzie, w 1960 roku, urodziła się Terry, Alicja Teresa, ich córka, a kilka lat później Janek sprowadził z Polski Martę - swoją córkę z pierwszego małżeństwa, z którą Marysię łączyły bardzo ciepłe i bliskie relacje. Zielińscy wyjechali z kraju na początku 1957 roku, zaproszeni przez siostrę Janka - Zosię do Holandii. Bardzo szybko zdecydowali, że nie wracają i rozpoczęli poszukiwania nowego miejsca do życia. Na ich listy pierwszy odpowiedział wuj Marysi z Toronto. Zdecydowali - jadą do Kanady. Najpierw były niezbyt udane miesiące w Toronto i problemy z pracą, których zupełnie się nie spodziewała. Z początkiem roku 1958, na zaproszenie koleżanki, Marysia wyjechała do Montrealu szukać lepszych warunków i przyszłości. W Montrealu mieszkali z Jankiem piętnaście lat, by w 1973 roku przeprowadzić się do Ottawy, gdzie Marysia przez ponad dwie dekady organizowała i kierowała Wielojęzycznym Serwisem Bibliotecznym (the Multilingual Biblioservice) przy Bibliotece Narodowej. Była to instytucja powołana przez premiera Pierre E. Trudeau jako jeden z instrumentów wprowadzających w Kanadzie program polityki pluralizmu kulturowego, zadeklarowaną przez premiera w 1971 roku. Marysia była pierwszym i jedynym szefem tej instytucji. W 1994 roku przeszła na emeryturę, co zbiegło się w czasie z istotnymi zmianami w kanadyjskiej polityce wielokulturowości, między innymi włączono the Multilingual Biblioservice w inne struktury Biblioteki Narodowej, w praktyce zlikwidowano tę placówkę.

2 Tekst napisany na bazie tak materiałów publikowanych jak i osobistych rozmów/relacji z Marysią, którą znałam wiele lat i spotykałyśmy się wielokrotnie w Ottawie a przede wszystkim w Krakowie. Bazą były także informacje przysłane przez działaczy organizacji polonijnych, w których działała M. Zielińska oraz Manning, R.,W.. (2017) , ed., A memory of Marie F. Zielinska, 1921-2016, „ELAN” no. 61 (Spring): s. 7.

3 Jego prawdziwe nazwisko to Mieczysław Roger. Zielińska, M., (2013) May You Live in Interesting Times: Memoirs of a Centenarian (Well, Almost), Ottawa: Baico Publishing, s. 149. 


\section{SM̂PP}

Była człowiekiem z krwi i kości, zawsze z entuzjazmem zabierała się do nowych projektów, nie bała się wyzwań, obdarzała serdecznością innych. Nie można zapominać o trudnym do przecenienie bagażu, jaki wyniosła z krakowskiego domu mocno powiązanego z intelektualno-artystyczną elitą miasta, schedzie, która z jednej strony pomagała układać sobie życie w nowym kraju, a z drugiej - nie pozwalała zapomnieć o tym, co pozostawiła w Polsce.

A rebours zacznę od jej kanadyjskiej drogi zawodowej i działalności na rzecz środowiska polonijnego, żeby dopiero na końcu pokazać jej dom rodzinny i wyjątkową atmosferę, jaka w nim panowała i w jakiej wzrastała Marysia.

Gdy Zielińscy przyjechali do Kanady, Marysia miała ukończone studia inżynieryjno-rolnicze na Uniwersytecie Jagiellońskim i podyplomowe kursy dziennikarstwa. Nie mogła jednak znaleźć pracy bliskiej jej kwalifikacjom. Po przeprowadzce do Montrealu próbowała szukać zajęcia w bibliotekach, wśród książek, z którymi miała tak bliski kontakt w krakowskim domu. Żeby do końca życia nie przekładać książek na półkach, a wykształcenie inżynieryjne nie dawało podstaw do awansu, musiała podnieść swoje kwalifikacje. W 1962 roku ukończyła licencjat z bibliotekoznawstwa na Universite de Montreal, a kilka lat później magisterium na McGill University4. Studiując pracowała w różnych bibliotekach Uniwersytetu Montrealskiego, między innymi organizowała i prowadziła bibliotekę Wydziału Biologii (1965-69), a w następnych trzech latach była szefem działu wydawnictw ciągłych dla całego zespołu bibliotek tego uniwersytetu.

Miała talent zjednywania sobie ludzi, potrafiła nimi kierować i tworzyć zgrane zespoły, wymagała wiele od siebie i pracowników, ale równocześnie starała się, by zespół lubił pracę i siebie nawzajem. Szybko poznano się na jej umiejętnościach organizacyjno-kierowniczych i w 1973 roku zaproponowano nową funkcję, jak mówiła „pracę marzenie”, stworzenie od podstaw serwisu bibliotecznego w ramach zadeklarowanego przez rząd Trudeau programu polityki pluralizmu kulturowego. Bez żalu opuszczała Montreal, mieszkała w Quebecu przed Spokojną Rewolucją, gdy kobieta nie miała nawet prawa samodzielnie wynająć mieszkania, i jak mawiała "ksiądz wchodził ludziom do łóżka", a w latach 60. XX w. obcy był jej rosnący w siłę quebecki nacjonalizm i tendencje separatystyczne w prowincji. Marysia była entuzjastką nowych wyzwań i przez następne dwadzieścia lat pracowała jako urzędnik federalny tworząc i rozwijając Wielojęzyczny Serwis Biblioteczny funkcjonujący przy kanadyjskiej Bibliotece Narodowej. Instytucja ta zaczynała od zbiorów w ośmiu językach, po dwóch dekadach, pod Marysi kierownictwem, zasoby obejmowały publikacje i inne materiały w ponad 60 językach. Wielojęzyczny serwis biblioteczny to program wspierania kanadyjskich grup etnicznych w utrzymaniu ich rodzimych języków, przyjęty w konsekwencji deklaracji polityki pluralizmu kulturowego, jaką złożył

${ }^{4}$ Zielińska, M., May You, s. 173-174. http://www.exlibris.ca/doku.php?id=history:biographies:biography_zielinska_mf [ data dostępu: 2018-09-23]. 
w 1971 roku premier Pierre E. Trudeau. Projekt ten polegał na stworzeniu instytucji, Multilingual Biblioservice, która miała gromadzić wydawnictwa, nagrania i inne materiały w językach, jakimi posługują się kanadyjskie grupy etniczne, innych niż dwa języki oficjalne. Kolejnym krokiem miała być organizacja sieci, poprzez którą można te zbiory wypożyczać i sprowadzać, via biblioteki publiczne, do najdalszych zakątków Kanady i tam z nich korzystać. Taką dobrze działającą instytucję i dystrybucję stworzył zespół prowadzony przez Marysię Zielińską ${ }^{5}$.

Przez te dwadzieścia lat współpracowała z bibliotekami w wielu krajach i publikowała w prasie branżowej. Jest współautorką pracy z zakresu organizacji i zasad działania wielojęzycznych bibliotek, która jest podręcznikiem na uniwersyteckich studiach bibliotekoznawczych w Kanadzié .

W 1979 roku współzałożyła the International Federation of Library Associations (IFLA), przez wiele lat zasiadała w jego zarządzie, a po przejściu na emeryturę pełniła tam honorowe funkcje. IFLA organizowała na całym świecie kongresy, na które Marysia zawsze jeździła. Czynnie uczestniczyła w pracach: the Canadian Library Association $(\mathrm{CLA})$, the Ottawa-Hull Library Association ( $\mathrm{LAOH})$, the American Library Association (ALA). Za pracę i działalność społeczną nadano jej wiele branżowych odznaczeń i nagród, honorowana była na wielu międzynarodowych kongresach bibliotekarzy, z czego była bardzo dumna. W podróżach niemal zawsze towarzyszył jej Janek, i to on opowiadał o sukcesach i honorach, jakie spotykały jego żonę. Można powiedzieć, że był jej rzecznikiem, choć dość osobliwym.

W 1994 roku z rąk Generalnego Gubernatora Kanady, Raya Hnatyshyna, otrzymała medal 125-lecia Federacji Kanadyjskiej, było to odznaczenie za zasługi dla Kanady, ale i wieńczące jej zawodowe życie w tym kraju.

Praca zawodowa była tylko częścią Marysi życia, wiele energii i czasu poświęciła także działalności na rzecz polskiej grupy etnicznej, najpierw w Montrealu, potem w Ottawie. Pracowała w instytucjach i organizacjach polonijnych, udzielała się także w rozmaitych akcjach na rzecz polonijnych środowisk. Związana była ze Szkołą Polską w Montrealu i Ottawie; Stowarzyszeniem Polskich Kombatantów, gdzie przez wiele lat prowadziła bibliotekę; Federacją Polek w Kanadzie; ottawskim oddziałem Kongresu Polonii Kanadyjskiej; Polskim Instytutem Naukowym w Kanadzie. Do Stowarzyszenia Polskich Inżynierów i Techników należała 55 lat, pełniła tam wiele funkcji, od sekretarki po najwyższe pozycje. Czynnie uczestniczyła w pracach Koła Przyjaciół KUL-u, działała w Stowarzyszeniu Twórców Ottawskich, pisała do wydawanego przez tą organizację MIXERA, udzielała się w klubie seniorów słowiańskiego pochodzenia

${ }^{5}$ Godin, J. (1994) Creating Multicultural Collections and Programs in Canadian Public Libraries, s. 1-19, http://www.nlc-bnc.ca/obj/005007/f2/005007-210.1-e.pdf [dostęp: 2018-09-24]. Zielińska M., (1976) Libraries in the Canadian mosaic: multilingual biblioservice, "Canadian Library Journal" 1976/33, no. 5 (October): 441-445.

${ }^{6}$ Zielińska, M.F., Kirkwood, F.T., (ed.), (1992) Multicultural librarianship: an international handbook, 


\section{SM̂PP}

"Ognisko"7. Marysia zawsze podkreślała swoją przynależności do polskiej tradycji katolickiej i języka polskiego; wspierała wszystkie instytucje związane z Kościołem katolickim i edukacją. W miejscach, w których działała, starała się zajmować także porządkowaniem dokumentacji bieżącej i archiwaliów, dbała o księgozbiory, choćby najskromniejsze. Mówiła, że po dziadku "ma to we krwi".

Miała niespożytą energię, prócz działań w różnych organizacjach udzielała się we wszystkich okazjonalnych poczynaniach - piekła ciasta na imprezy/kiermasze charytatywne, szyła stroje dla dzieci na polonijne okazje, uczyła polskich tańców i piosenek, wycinała znaczki w ramach kolejnych akcji charytatywnych, w razie potrzeby kwestowała. W stanie wojennym zaangażowała się w organizowanie pomocy dla Polski, współorganizowała wysyłkę ponad 10 ton darów. W latach 1980-1984 mocno wspierała wielką akcję sponsoringu do Kanady polskich emigrantów. Polonia uczestniczyła wówczas w sprowadzeniu i pomocy w zagospodarowaniu się w Kanadzie około 25 tyś tzw. emigrantów solidarnościowych ${ }^{8}$. Nie ukrywała, że smutkiem napawa ją, że „w życiu emigracyjnym poszczególne fale przybyszów nie mieszają się ze sobą, tworzą własne grupy towarzyskie i społeczne, a kontakty ze starszą emigracją nie przekraczają okolicznościowych spotkań" ${ }^{\prime}$. Nie zrażało ją to jednak i zawsze była gotowa do niesienia pomocy wszystkim, bez względu na to, do której fali emigracyjnej należeli. Twierdziła, że potrzebę pomocy innym wyniosła z krakowskiego rodzinnego domu, że wielu ludzi pomogło jej, gdy wyjechała z Polski, więc ona też nie potrafi pozostać obojętną.

Za swoją działalność, pracę, życzliwość dla ludzi była nagradzana wielokrotnie medalami, dyplomami, adresami nadawanymi i wręczanymi jej przez polonijne organizacje i środowiska. Otrzymała między innymi srebrną i złotą Odznakę Federacji Światowej SPK oraz takież od Kongresu Polonii Kanadyjskiej. Od państwa polskiego otrzymała dwa medale, które wysoce ceniła i była bardzo wzruszona oficjalnymi uroczystościami z tym związanymi, jakie miały miejsce w ambasadzie wolnej Polski w Ottawie. W 2002 roku uhonorowana została Złotym Krzyżem Zasługi, a w roku 2008 - Krzyżem Kawalerskim Orderu Zasługi Rzeczypospolitej Polskiej nadawanym osobom mieszkającym poza granicami Kraju'10.

7 Order dla Marii Zielińskiej. Wieści Polonijne, „Związkowiec”, 10 października, 2002. Ta część tekstu napisana została także na podstawie rozmów i korespondencji mailowej z osobami działającymi w polonijnych organizacjach w Montrealu i Ottawie, między innymi z: Bogdanem Gajewskim, Jerzym Kulczyckim i Ewą Zadarnowską.

8 Kijewska-Trembecka, M., ( 2001) The Solidarity Emigration - The Last Wave of Polish Immigrants tro Canada, [w] Proceedings/Actes, Individual and Community: Canada in the $20^{\text {th }}$ Century / L'individuel et la communaute: le Canada au 20 sciecle, Bucharest, October/octobre 2001, Brno: Masaryk University, s. $241-247$.

${ }^{9}$ Zielińska, M., (1998) Opowieść dla córki, Ottawa: nakładem autora, s. 105.

10 Order dla Marii Zielińskiej....; http://www.exlibris.ca/doku.php?id=history:biographies:biography zielinska_mf [dostęp: 2018-09-14]. 
W 1998 roku napisała w swoim pamiętniku „życie niestety nie oszczędza smutnych i bolesnych ciosów", ${ }^{11}$ dla Marysi takim ciosem był brak zainteresowania ze strony jedynej, ukochanej córki dla przekazywania swoim dzieciom, a wnukom Marysi i Janka, języka polskiego i tradycji rodzinnych. „Wbrew obietnicy złożonej z własnej, a nie przymuszonej woli, Teresa odcięła swoje dzieci od nauki języka polskiego i wykreśliła język przodków ze swego domu"12. To Marysię bardzo bolało, bo jej marzeniem było, aby Terry wyszła za mąż za Polaka ${ }^{13}$. Poślubiła Włocha. Tu pocieszeniem, choć trochę przez łzy, było to, że obie córki Marty, mówią pięknie po polsku.

Marysia Zielińska, ze swoją szlachetnością i swoimi słabościami, kochała życie. Mówiła, że na jej wizję życia wielki wpływ miała sztuka Drzewa umierają stojąc Alejandro Casony, którą w latach 50. XX w. zobaczyła w polskim teatrze ${ }^{14}$. Była zawsze uśmiechnięta i przyjazna ludziom. Prowadzili z Jankiem bogate życie towarzyskie, głównie polonijne, uwielbiała bale i rauty, spotkania przy kawie i ciastkach, była łasuchem. Kochała Kanadę, ale zawsze na pierwszym miejscu był Kraków, do niego tęskniła. Najlepsze ciastka na świecie-porównywała z tymi z krakowskiego Noworola, który zawsze wychodził zwycięsko z tej rywalizacji. Wraz z Jankiem żyli w Ottawie dość skromnie, przez ponad 30 lat wynajmowali niewielkie mieszkanie na 8 piętrze w bloku nad Ottawą, ale adres 330 Driveway był zawsze otwarty dla ludzi z Polski. Mówiła jednak, że nie chce wracać do ukochanego Krakowa w trumnie, zostanie razem ze swoimi najbliższymi w Kanadzie.

Marysia nieodmiennie podkreślała, że to z rodzinnego domu wyniosła bagaż wartości i otwartość na ludzi, z których całe życie czerpała. Jej krakowska familia i środowisko, w którym się obracała, były wyjątkowe.

Rodziny, zarówno matki jak i ojca, należały do elity przedwojennej Galicji, Lwowa i Krakowa. Marysia zawsze najcieplej mówiła o ojcu, Zbigniewie Odrzywolskim, architekcie ze znanej w Krakowie rodziny ziemian i architektów Odrzywolskich herbu Nałęcz. Przez swoją babkę ze strony ojca Marysia należała także do innej znanej rodziny Saskich herbu Sas, czyli jak mówi się w Krakowie Sas-Saskich. Zaś stryjem jej ojca był słynny Sławomir Odrzywolski, ważny krakowski architekt, projektant wielu secesyjnych i modernistycznych budowli w centrum Krakowa i nie byle jaki konserwator zabytków. Był między innymi głównym projektantem i osobą nadzorującą konserwację Katedry na Wawelu w końcu XIX wieku. Przez ojca skoligacona była także, i to dość blisko, z rodziną Żeromskich, a akcja Wiernej rzeki rozgrywa się w Rudzie Zajączkowskiej, w jednym z majątków Saskich, gdzie Żeromski wielokrotnie przebywał. Kiedy dorastała, ojciec był dla niej najważniejszy, wspólnie spędzali wiele czasu w Brzączowicach koło Myślenic, majątku, który kupił w połowie

11 Zielińska, M., Opowieść..., s. 105.

12 Ibidem, s. 104.

13 Ziółkowska, A., (1986) Kanada, Kanada, Warszawa: Wydawnictwo Polonia, s. 47.

14 Zielińska, M., May You ..., s. 216. 


\section{SM̂PP}

lat 30. XX w., gdzie Marysia, jak wspominała z nostalgią, z wielką przyjemnością jeździła wierzchem i zajmowała się końmi. Tam też wraz z ojcem przebywała w czasie wojny.

Jednak na pierwszych kilkunastu latach życia Marysi najmocniej zaważył kto inny - jej dziadek ze strony matki - jak o niej mówiła najczęściej. To Leon Samuel Sternbach (1864-1940) - słynny bizantynista i filolog klasyczny, profesor UJ. Obok Karla Krumbachera uznawany był za najwybitniejszego bizantynistę na świecie. To w jego gabinecie Marysia buszowała po półkach z książkami, a wieczorami słuchała jak opowiadał niezwykłe historie. Mówiła, że dzięki niemu kochała książki i pół życia im poświęciła ${ }^{15}$. Rodzinny dom Sternbachów był niezwykły, Marysia z rodzicami przez wiele lat mieszkała w kamienicy dziadka przy ulicy Batorego 14. Leon Samuel Sternbach urodził się w Drohobyczu w rodzinie podrabina i hebraisty, jego żona pochodziła także z zacnej, religijnej i bogatej żydowskiej rodziny Epsteinów. Prof. Sternbach blisko znał wielkich tamtych czasów. Podczas pobytów w Rzymie, w archiwum i bibliotece watykańskiej, zaprzyjaźnił się kardynałem Rattim, późniejszym Piusem XI, na prywatnych audiencjach przyjmował profesora król Wiktor Emanuel III. Był wielce szanowany wśród europejskich elit intelektualnych, proponowano mu prestiżowe stanowiska, ale nie przyjął ani katedry bizantynistyki na uniwersytecie w Wiedniu, ani posady w Watykanie, gdyż uważał, że jego miejsce jest w ojczyźnie, na UJ w Krakowie ${ }^{16}$. W Krakowie, w domu na Batorego, bywali artyści i profesorowie, krakowska elita intelektualna i artystyczna. Dziadek Marysi współpracował z Wyspiańskim, gdy ten pisał swoje antyczne dramaty, a znany portret rodziny Sternbachów wyszedł spod ręki właśnie Stanisława Wyspiańskiego. Helenka Sternbachówna to matka Marysi, jedyna córka Leona i Leontyny ${ }^{17}$.

Prof. Sternbach, mimo że był już kilka lat na emeryturze, zgłosił się do pracy na uniwersytecie $w$ roku akademickim 1939/40 i wraz z innymi profesorami został aresztowany $w$ ramach akcji Sonderaktion Krakau. Zmarł w obozie Sachsenhausen wiosną 1940 roku, jego symboliczny grób znajduje się na cmentarzu żydowskim przy ulicy Miodowej w Krakowie. Jak podaje H. Grynberg, w latach międzywojennych, imię dziadka Marysi nosiło prywatne, elitarne, żydowskie gimnazjum w Drohobyczu ${ }^{18}$.

W rodzinie Sternbachów było jeszcze kilka znanych postaci, w szczególności profesor Leon Henryk Sternbach. To wuj Marysi, znany amerykański chemik i farmaceuta,

${ }^{15}$ Zielińska, M., Opowieść..., s. 5-16. Wielki księgozbiór prof. Sternbacha, ok. 40 tyś. woluminów, przekazany został Bibliotece Jagiellońskiej, ibidem.

16 http://www.ipsb.nina.gov.pl/a/biografia/leon-samuel-sternbach [dostęp: 2018-09-14].

17 W spadku Marysia dostała portret dziadka pędzla Wyspiańskiego, nie mogła go wywieź z Polski, miał czekać na nią w domu na Batorego 19, nie doczekał jednak. Kilka lat temu, bez jej zgody, został sprzedany przez siostrzeńca Marysi, na warszawskiej aukcji. http://www.gazetakrakowska.pl/artykul/533883, pastele-wyspianskiego-sprzedane-za-prawie-2-mln-zl,id,t.html [dostęp: 2018-08-28].

18 http://www.ipsb.nina.gov.pl/a/biografia/leon-samuel-sternbach [dostęp: 2018-09-14]. 
absolwent Uniwersytetu Jagiellońskiego, wynalazca valium dla firmy La-Roche, który zmarł w USA w 2005 roku $^{19}$.

Marysia miała o 10 lat młodszą siostrę, Julitę imię dla niej wymyślił dziadek Leon, z którą nigdy nie łączyły jej bliskie relacje. Jak mówiła „Julita była z matką, ja z tatą”. Do końca życia pozostały w konflikcie, siostra mieszkała w Krakowie przy ulicy Batorego 19, w tzw. nowym domu, czyli kamienicy z oficynami wybudowanej przez ich ojca w końcu lat 20. XX w., gdzie rodzina przeniosła się w początku lat 30. Podział majątku był jednym z mocnych elementów sporu między siostrami.

Marysia ukończyła znane krakowskie gimnazjum im. Królowej Jadwigi, które mieściło się w tych samych pomieszczeniach, gdzie znajduje się obecnie Instytut Amerykanistyki i Studiów Polonijnych UJ, w Rynku Głównym 34, i tuż przed wojną zdała tam maturę. Wojenne czasy spędziła w Brzączowicach z ojcem, a siostra z matką, w bardziej odległym i mniej widocznym miejscu, w Poradowie koło Miechowa, gdzie rodzina Saskich miała folwark. Marysia, podobna do ojca, w żaden sposób nie wyróżniała się wśród młodych dziewcząt, z kolei Julita o bardziej semickich rysach, podobnie jak matka, może zbyt rzucała by się w oczy.

Po wojnie Marysia studiowała rolnictwo na UJ, tak chciał zarówno ojciec, jak i ona. Po latach spędzonych w Brzączowicach, chciała zajmować się końmi. Jednak po rozparcelowaniu majątku w ramach reformy rolnej plany legły w gruzach. Ukończyła też w Krakowie pomaturalne kursy dziennikarstwa. Ojciec zmarł w 1948 roku, a w styczniu 1950 roku wzięła w Zakopanem cichy, trochę potajemny, cywilny ślub z Jankiem Zielińskim. Byli razem aż do śmierci Janka w 2004 roku, ponad pół wieku²0.

Na koniec krótki komentarz, który z pewnością nie będzie zaskoczeniem dla badaczy spraw polonijnych. Przy takim bagażu kulturowo-rodzinnym, w jaki wyposażona została Marysia, nigdy - ani w rozmowach i opowiadaniach, jakie miały miejsce i w Ottawie i u nas w Krakowie, w Brzączowicach i innych okolicznościach, także w żadnym miejscu w swoich spisanych wspomnieniach - nie odniosła się do swoich żydowskich korzeni. Zupełnie to wyparła. Jej matka była po prostu córką prof. Sternbacha, krakowskiego uczonego. Matka przeszła z pewnością na katolicyzm, bo Marysia pisze o wspólnym chodzeniu do Kościoła karmelitów na Piasku. Nic jednak nie wiadomo na temat ślubu, jaki i kiedy, wzięli rodzice Marysi - Helena Sternbach i Zbigniew Odrzywolski. W swoich wspomnieniach wraca do drobiazgów, pisze jak wyglądał tort urodzinowy i jak ułożone były książki na półkach, oraz jak babcia pakowała swoje kapelusze przed podróżą do Rzymu. Pisze o dalekich i skomplikowanych koligacjach rodzinnych, które wyjaśnia ze szczegółami, a o ślubie swoich rodziców jedynie tyle: „Mój ojciec urodził się 2 marca 1883 roku, był synem Zofii Saskiej. Ożenił

19 Sławiński, B., Wynalazca nad wynalazcami, http://www2.almamater.uj.edu.pl/93/14.pdf [dostęp: 2018-09-04].

20 Janek był rozwodnikiem, Marysia mocno przywiązana do tradycji Kościoła katolickiego, bolała, że nie mogą wziąć ślubu kościelnego, stało się to możliwe po, jak mówiła, anulowaniu poprzedniego małżeństwa Janka. Ślub wzięli w 1964 roku w Montrealu. Zielińska,M., May You..., s. 130-135. 


\section{SM̂PP}

się z Heleną Sternbach i miał dwie córki"21. Koniec informacji. Także nigdy i nigdzie nie mówiła ani nie napisała o Iwowskiej rodzinie Janka/Mieczysława. Raz jedyny przytoczyła jego prawdziwe nazwisko, ale zdjęcia rodziców Janka są bezimienne, ani imion ani nazwisk, tylko fotografie ${ }^{22}$. Janek był w ogóle bardzo tajemniczą postacią.

Jak wspomniałam, dla nas, badaczy dziejów Polonii, taka sytuacja to nic nadzwyczajnego.

\section{Bibliografia}

Kijewska-Trembecka, M., ( 2004), The Solidarity Emigration - The Last Wave of Polish Immigrants to Canada,w: Proceedings/Actes, Individual and Community: Canada in the 20 ${ }^{\text {th }}$ Century / L'individuel et la communaute: le Canada au 20 sciecle, Bucharest, October/octobre 2001, Brno: Masaryk University.

Zielinska, M., Kirkwood, F.T., (1992), ed. Multicultural librarianship: an international handbook. München: K.G. Sauer.

Zielińska, M., (1998), Opowieść dla córki, Ottawa: nakładem autora.

Zielińska, M., (2013), May You Live in Interesting Times: Memoirs of a Centenarian, Ottawa Baico Publishing.

Ziółkowska, A., (1986), Kanada, Kanada, Warszawa: Wydawnictwo Polonia.

Manning, R.W. (2017), (ed.), A memory of Marie F. Zielinska, 1921-2016, „ELAN “ no. 61 (Spring): s. 7.

Order dla Marii Zielińskiej. Wieści Polonijne, (2002), „Związkowiec”, 10 października.

Zielińska, M., (1976) Libraries in the Canadian mosaic: multilingual biblioservice, " Canadian Library Journal" 1976/33, no. 5 (October): 441-445.

Godin, J., (1994) Creating Multicultural Collections and Programs in Canadian Public Libraries, http://www.nlc-bnc.ca/obj/005007/f2/005007-210.1-e.pdf. (dostęp: 2018-09-24)

Order dla Marii Zielińskiej...; http://www.exlibris.ca/doku.php?id=history:biographies:biography zielinska_mf (dostęp: 2018-09-14)

Sławiński Bogusław, Wynalazca nad wynalazcami,

http://www2.almamater.uj.edu.pl/93/14.pdf (dostęp: 2018-09-04)

http://www.gazetakrakowska.pl/artykul/533883, pastele-wyspianskiego-sprzedane-za-prawie-2mln-zl,id,t.html (dostęp: 2018-08-28)

http://www.ipsb.nina.gov.pl/a/biografia/leon-samuel-sternbach (dostęp: 2018-09-14)

a także

- korespondencja mailowa z działaczami polonijnych organizacji w Montrealu i Ottawie

- rozmowy Autorki z Marysią Zielińską i Jankiem Zielińskim na przestrzeni wielu lat znajomości.

21 Ibidem, s. 35.

22 Ibidem, s. 42; M Zielińska, Opowieść..., s. 95. 